\title{
Selective Extraction and "One-Drop" Flame Atomic Absorption Spectrometric Determination of Silver in Biological Standard Reference Materials
}

\author{
Isao KoJima and Miwa KatsuzaKI \\ Laboratory of Analytical Chemistry, Department of Applied Chemistry, Nagoya Institute of Technology, \\ Gokiso-cho, Showa, Nagoya 466, Japan
}

\begin{abstract}
Keywords Flame atomic absorption spectrometry, solvent extraction, silver, 3,6-dithiaoctane, zoological and botanical standard reference materials, microwave-assisted acid digestion
\end{abstract}

For the selective extraction of silver as a ternary complex in the presence of a bulky counter ion, such as picrate ion, thiacrown ethers ${ }^{1-4}$ and acyclic polythiaalkanes $^{5-8}$ are recommended as extractants. Perchlorate ion is also used as a bulky counter anion in the extraction of a cationic metal complex. Perchloric acid is frequently used as a powerful oxidizing agent for the wet-digestion of biological samples. Thus, the direct extraction of a cationic metal complex- $\mathrm{ClO}_{4}^{-}$associate from the digested sample solution could be the simplest and the most convenient way to separate a trace metal of interest.

By one-drop flame atomic absorption spectrometry (FAAS) with the direct nebulization of $50 \mu \mathrm{l}$ of the organic extract into a fuel-lean air-acetylene flame, some elements $^{9-11}$ have been sensitively determined without any background correction.

The present paper describes the selective extraction of silver with commercially available 3,6-dithiaoctane (8-2S) from a $0.5 \mathrm{~mol} \mathrm{dm}^{-3} \mathrm{HClO}_{4}$ solution and the onedrop FAAS of silver in three zoological and six botanical standard reference materials without a deuterium background correction.

\section{Experimental}

\section{Apparatus}

An atomic absorption spectrometer (Seiko Model SAS-727, Chiba, Japan) was used for silver measurement under ordinary operating conditions at 328.1 nm. ${ }^{12}$ An unmodified Hitachi (MR-M 201) microwave oven (Tokyo, Japan) and a closed double-PTFE digestion bomb with a polypropylene jacket (San-ai Kagaku, Nagoya, Japan) were used for sample digestion. First, $50 \mu \mathrm{l}$ of the chloroform extract was injected with a micropipette (Gilson P-200, France). The FAAS signal was recorded on a strip-chart recorder (National, VP6612A, Osaka, Japan).

\section{Reagents}

A silver stock solution $\left(2 \mathrm{mg} \mathrm{g}^{-1}\right.$ in $0.5 \mathrm{~mol} \mathrm{dm}^{-3}$ $\mathrm{HNO}_{3}$ ) was prepared by dissolving silver $(99.99 \%$ purity, Nacalai Tesque, Kyoto, Japan) in $\mathrm{HNO}_{3}$ directly in a PTFE bottle of $120 \mathrm{~cm}^{3}$ capacity, followed by diluting by mass with water. Working aqueous standard solutions were prepared by diluting the stock solution to the appropriate concentrations by mass with $0.1 \mathrm{~mol} \mathrm{dm}^{-3}$ $\mathrm{HNO}_{3}$. Commercially available 8-2S (Wako, Osaka, Japan) of an analytical-reagent grade was directly dissolved in chloroform $\left(0.05 \mathrm{~mol} \mathrm{dm}^{-3}\right)$. Chloroform of analytical-reagent grade (Wako) was used without further purification. The acids used for sample digestion were of analytical-reagent grade (Wako). Water purified by a Milli-Q system (Millipore, USA) was used throughout.

\section{Decomposition of a biological sample}

A dry sample was put with an acid mixture in an inner Tuf-Tainer vial (Pierce, USA) of 7 or $15 \mathrm{~cm}^{3}$ capacity placed in an outer PTFE vessel of 25 or $50 \mathrm{~cm}^{3}$ capacity containing $3 \mathrm{~cm}^{3}$ of $1 \mathrm{~mol} \mathrm{dm}^{-3} \mathrm{NaOH}$ solution. The sample was decomposed by microwave-assisted heating, as was done in a previous study. ${ }^{13}$ The digest in the inner vial was completely evaporated to dryness. The dry residue was dissolved in $3.0-4.0 \mathrm{~cm}^{3}$ of a $0.5 \mathrm{~mol}$ $\mathrm{dm}^{-3} \mathrm{HClO}_{4}$ solution in the same vial. On the basis of the silver content in the reference materials, the sample mass, volume of the acid mixture, power of the microwave oven and the microwave-assisted heating time were varied, as given in Tables 1 and 2.

\section{Extraction procedure}

Into a $10 \mathrm{~cm}^{3}$ stoppered glass test-tube, all of the final sample solutions ( 3 or $4 \mathrm{~cm}^{3}$, weighed) and 0.3 or $0.4 \mathrm{~cm}^{3}$ (weighed) of a chloroform solution of $8-2 \mathrm{~S}(0.05 \mathrm{~mol}$ $\mathrm{dm}^{-3}$ ) were placed. Silver was extracted by shaking for $10 \mathrm{~s}$ (three times) by hand. For a calibration curve, $5 \mathrm{~cm}^{3}$ (weighed) of the standard solution containing $0-0.1 \mu \mathrm{g}$ 
Table 1 Sample mass, volume of acid mixture and microwave heating time

\begin{tabular}{|c|c|c|c|c|c|}
\hline \multirow{2}{*}{$\begin{array}{c}\text { Sample mass/ } \\
\text { mg }\end{array}$} & \multicolumn{4}{|c|}{ Acid mixture $/ \mathrm{cm}^{-3}$} & \multirow{2}{*}{$\begin{array}{c}\text { Heating time/ } \\
\min ^{\mathrm{b}}\end{array}$} \\
\hline & $\mathrm{HNO}_{3}$ & $\mathrm{HClO}_{4}$ & $\mathrm{HCl}$ & $(H F)^{a}$ & \\
\hline 100 & 2.0 & 0.3 & 0.1 & 0.1 & $4+4$ \\
\hline 200 & 3.0 & 0.5 & 0.3 & 0.3 & $4+4$ \\
\hline 300 & 5.0 & 1.0 & 0.5 & 0.5 & $4+4.5$ \\
\hline
\end{tabular}

a. HF was not used for zoological samples.

b. Power of microwave oven was always $200 \mathrm{~W}$.

First heating was carried out with $100 \mathrm{~cm}^{-3}$ water in a beaker and the second without water.

of silver was shaken with $0.5 \mathrm{~cm}^{3}$ (weighed) of chloroform solution. A $50 \mu \mathrm{l}$ aliquot of the chloroform extract was used for an FAAS measurement, as described in our previous paper. ${ }^{8}$ On the basis of the silver content in standard reference materials, the sample mass, volume of the final sample solution, volume of the chloroform solution of $8-2 \mathrm{~S}$ and the calibration range were chosen; these are summarized in Table 2.

\section{Results and Discussion}

\section{Effect of the perchloric acid concentration on extraction}

In a previous study ${ }^{8}$, picric acid was used as a bulky counter anion in the extraction of the cationic silver-8-2S complex at a pH higher than unity. If $\mathrm{ClO}_{4}^{-}$is used instead of picric acid, the extraction procedure will be simpler, owing to the complete dissociation of $\mathrm{HClO}_{4}$ at any $\mathrm{pH}$. In the digestion of biological samples, the final sample solutions were prepared by dissolving the digested residue in the $\mathrm{HClO}_{4}$ solution. ${ }^{8-10}$ For these reasons, the effect of $\mathrm{HClO}_{4}$ concentration on the silver extraction was tested. The extraction of silver was quantitative $\left(99.7 \%\right.$ ) and constant at $0.1-1.0 \mathrm{~mol} \mathrm{dm}^{-3}$ $\mathrm{HClO}_{4}$ concentration. Even when $\mathrm{NaClO}_{4}$ replaced
$\mathrm{HClO}_{4}$, the extraction of silver was also quantitative. Since 8-2S is a neutral ligand, even in an acid medium, the extraction of the ternary silver-8-2S- $\mathrm{ClO}_{4}^{-}$complex is $\mathrm{pH}$-independent. This makes the present extraction system much simpler. On the other hand, the injection of the chloroform extract obtained from the higher $\mathrm{HClO}_{4}$ concentration gave a slightly higher FAAS signal, compared with that from a $0.1 \mathrm{~mol} \mathrm{dm}^{-3} \mathrm{HClO}_{4}$ solution. This increase in the FAAS signal was about $7 \%$ and also constant for the extract from above $0.5 \mathrm{~mol} \mathrm{dm}^{-3} \mathrm{HClO}_{4}$ concentration. However, the reasons why this occurs are not known. Some samples contain a rather high concentration of metals, and the metals in the residue may be present as their perchlorate salts. This high metal content causes a high total $\mathrm{ClO}_{4}{ }^{-}$concentration in the final sample solution besides the $\mathrm{HClO}_{4}$ used in preparing the final sample solution (see Table 2). For example, the $\mathrm{ClO}_{4}{ }^{-}$concentration in the botanical sample studied here was $0.10-0.37 \mathrm{~mol} \mathrm{dm}^{-3}$ in the final sample solution, and less than $0.10 \mathrm{~mol} \mathrm{dm}^{-3}$ in a zoological sample, supposing that precipitation does not occur during the course of preparing the final sample solution. This high $\mathrm{ClO}_{4}^{-}$concentration could cause the precipitation of potassium perchlorate in the final sample solution. Although, Hijiki, Tomato Leaves and Sargasso caused precipitation, the recovery of silver in Sargasso was satisfactory. From this result, the silver recovery in even Hijiki and Tomato Leaves seems to be reasonable. Taking into account of the variation in the total $\mathrm{ClO}_{4}{ }^{-}$ concentration and the increase in the FAAS signal, the extraction of silver from a $0.5 \mathrm{~mol} \mathrm{dm}^{-3} \mathrm{HClO}_{4}$ solution is recommended based on this study.

\section{Analytical features of the present method}

The calibration curve obtained by injecting $50 \mu \mathrm{l}$ of the chloroform extract gave a very good straight line with a very small intercept. The reproducibility was also $1.2 \%$ at $0.1 \mu \mathrm{g} \mathrm{cm}^{-3}$ of $\mathrm{Ag}$ in the chloroform extract, and the detection limit was $4 \mathrm{ng} \mathrm{cm}^{-3}(S / N=3)$.

Table 2 Sample mass, volumes of final sample solution and chloroform solution of 8-2S and calibration range used for silver determination

\begin{tabular}{lcccccc}
\hline Sample & Sample mass $/ \mathrm{mg}$ & $\begin{array}{c}\mathrm{K} \text { content, } \\
\%\end{array}$ & $\begin{array}{c}\text { Sample soln./ } \\
\mathrm{cm}^{-3}\end{array}$ & $\begin{array}{c}{\left[\mathrm{ClO}_{4}^{-}\right] /} \\
\mathrm{mmol} \mathrm{dm}^{-3}\end{array}$ & $\mathrm{CHCl}_{3} / \mathrm{cm}^{-3}$ & $\mathrm{Range}^{\prime} \mathrm{g} \mathrm{cm}^{-3}$ \\
\hline Oyster Tissue & 100 & 0.97 & 4.0 & 17 & 0.4 & $0-0.4$ \\
Bovine Liver & 300 & 0.98 & 3.0 & 43 & 0.3 & $0-0.2$ \\
Mussel & 300 & 0.54 & 3.0 & 90 & 0.3 & $0-0.2$ \\
Orchard Leaves & 300 & 1.47 & 3.0 & 195 & 0.3 & $0-0.2$ \\
Tomato Leaves & 300 & 4.46 & 3.0 & 249 & 0.3 & $0-0.2$ \\
Spinach & 100 & 3.56 & 3.0 & 78 & 0.3 & $0-0.2$ \\
Pepperbush & 300 & 1.51 & 3.0 & 151 & 0.3 & $0-0.2$ \\
Sargasso & 200 & 6.1 & 4.0 & 177 & 0.4 & $0-0.2$ \\
Hijiki & 200 & 19.2 & 4.0 & 373 & 0.4 & $0-0.2$ \\
\hline
\end{tabular}

$\left[\mathrm{ClO}_{4}^{-}\right]$: hypothetical perchlorate ion concentration in the final sample solution, i.e., the calculated values when all the metals in the sample solution are considered to exist as perchlorate salts. Content of K: certified or reported value in samples. ${ }^{14-17}$ 
Table 3 Analytical results for silver in biological reference materials $(n=3)$

\begin{tabular}{llccc}
\hline \multirow{2}{*}{ Sample } & & \multicolumn{2}{c}{ Content/ng g-1 } & \multirow{2}{*}{ Ref. } \\
\cline { 3 - 4 } & & Found & Reported & \\
\hline Oyster Tissue & (NIST-SRM 1566) & $960 \pm 10$ & $940 \pm 110^{\mathrm{a}}$ & 14 \\
Bovine Liver & (NIST-SRM 1577) & $67 \pm 2$ & $62 \pm 13^{\mathrm{a}}$ & 14 \\
Mussel & (NIES-CRM No. 6) & $26 \pm 1$ & $27 \pm 3^{\mathrm{a}}$ & 15 \\
Orchard Leaves & (NIST-SRM 1571) & $25 \pm 3$ & $320 \quad(n=2)^{\mathrm{b}}$ & 14 \\
Tomato Leaves & (NIST-SRM 1573) & $32 \pm 3$ & $180 \quad(n=1)^{\mathrm{b}}$ & 14 \\
Spinach & (NIST-SRM 1570) & $28 \quad(n=1)$ & $65 \quad(n=1)^{\mathrm{b}}$ & 14 \\
Pepperbush & (NIES-CRM No. 1) & $40 \pm 2$ & $34(n=1)^{\mathrm{a}}$ & 16 \\
Sargasso & (NIES-CRM No. 9) & $311 \pm 5$ & $310 \pm 20^{\mathrm{a}}$ & 17 \\
Hijiki & (NIES-CRM No. 14) & $15 \pm 3$ & - & - \\
\hline
\end{tabular}

a. The certified or consensus value. b. Non-certified value.

\section{Determination of silver in biological samples}

The present method was applied in the determination of silver in biological standard reference materials from the National Institute of .Standards and Technology (NIST, USA) and the National Institute for Environmental Studies (NIES, Japan). The materials used were NIST-SRM 1566 Oyster Tissue, 1577 Bovine Liver, 1571 Orchard Leaves, 1573 Tomato Leaves, 1570 Spinach, NIES-CRM No. 6 Mussel, No. 1 Pepperbush, No. 9 Sargasso and No. 14 Hijiki. The analytical results are given in Table 3 along with the certified or consensus values. The results for the NIES standards agreed well with the reported values, irrespective of the zoological or botanical samples. Although the values for the zoological NIST standards were in good agreement with the certified values, the values for botanicals were less than those reported. The silver content for Orchard Leaves did not change with or without the use of $\mathrm{HCl}$ in the digestion step. The higher chlorine content in Oyster Tissue (1\%) and Sargasso $(5.1 \%)$ did not affect their silver contents found in the present study. The reasons why the chlorine content did not affect the silver recovery were the complete removal of chlorine during the course of the drying step of the digest and no $\mathrm{AgCl}$ precipitation at this lower silver concentration less than $10^{-7} \mathrm{~mol} \mathrm{dm}^{-3}$. The latter is easily estimated from the conditional solubility product, by taking into account of the formation of the chloro-complex. Judging from these results and the data of three zoological and two NIES botanical standards, the reported values for the three NIST botanicals (Orchard Leaves, Tomato Leaves and Spinach) are erroneous.

\section{References}

1. D. Sevdec, L. Fekete and H. Meider, J. Inorg. Nucl. Chem., 42, 885 (1980) and papers cited therein.
2. M. Oue, K. Kimura and T. Shono, Anal. Chim. Acta, 194, 293 (1987).

3. M. Oue, K. Kimura and T. Shono, Analyst [London], 113, 551 (1988).

4. E. Sekido, K. Saito, Y. Naganuma and H. Kumazaki, Anal. Sci., 1, 363 (1985).

5. F. Dietze, K. Gloe, R. Jacobi, P. Muhl, J. Beger, M. Perich, L. Beyer and E. Hoyer, Solvent Extr. Ion Exchange, 7, 223 (1989).

6. E. Lachowicz, Analyst [London], 112, 1623 (1987).

7. A. Ohki, M. Takagi and K. Ueno, Anal. Chim. Acta, 159, 245 (1984).

8. I. Kojima and A. Takayanagi, J. Anal. At. Spectrom., 11, 607 (1996).

9. I. Kojima and S. Kondo, J. Anal. At. Spectrom., 8, 115 (1993).

10. I. Kojima and S. Nomura, Anal. Sci., 11, 17 (1995).

11. I. Kojima and A. Suzuki, Bunseki Kagaku, 42, 435 (1993).

12. I. Kojima, K. Inagaki and S. Kondo, J. Anal. At. Spectrom., 9, 1161 (1994).

13. I. Kojima, A. Kato and C. Iida, Anal. Chim. Acta, 264, 101 (1992).

14. E. S. Gladney, B. T. O'Malley, I. Roelandts and T. E. Gills, "Standard Reference Materials: Compilation of Elemental Concentration Data for NBS Clinical, Biological, Geological and Environmental Standard Reference Materials", 1987, National Bureau of Standards, Spec. Publ. 260-111.

15. K. Okamoto and K. Fuwa, Analyst [London], 110, 785 (1985).

16. K. Okamoto (ed.), "Preparation, Analysis and Certification of Pepperbush Standard Reference Materials", Research Report No. 38, Natl. Inst. Environ. Studies, 1980.

17. K. Okamoto, Kikan Kannkyou Kagaku, No. 71, 1 (1988). 